\title{
OBSERVAÇÕES SOBRE AS MODIFICAÇÕES EM CUR- SO NA ENTRADA DE CANANEIA DE SUA BARRA E DA REGIÃO ADJACENTE
}

\section{Introdução}

A região lagunar de Iguape-Cananéia, possue três pontos de comunicação com o mar: as barras de Icaparra, Cananéia e Ararapira. Das três, a de Cananéia é a principal via pela qual se processam os movimentos do mar e é a única usada na navegação, visto estarem as outras obstruídas, podendo servir só para pequenas embareações e assim mesmo durante a enchente. As barras de Icaparra e de Ararapira, portanto, podem ser consideradas como secundárias, tendo apenas importância local. De fato, a primeira mencionada serve para a descarga de águas da Ribeira de Iguape e para o jôgo das marés numa região limitada. Normalmente, sua influência não ultrapassa uns trinta quilômetros ao Sul, no Mar Pequeno. Quanto à barra de Ararapira, sua influência no sistema lagunar é ainda menor, resumindo-se ao papel de regulador dos movimentos da maré na parte SW do sistema.

Isso pôsto, conclue-se que a entrada de Cananéia é, primeiramente, a via de comunicação principal entre o Oceano e a massa de águas interiores e, em segundo lugar, é a única via de acesso para a navegação, tanto para o pôrto de Cananéia, como para a Base de Pesquisas do Instituto.

Como é habitual em tôdas as regiões de costas arenosas e sobretudo de "restingas", ocorrem sempre diversas modificações que dependem, em parte, da acumulação de material arenoso e, por outra, da erosão das margens da entrada pelo efeito conjugado das correntes de maré e das ondas.

No caso presente, essas modificações pareciam se desenvolver lentamente e numa direção determinada. Assim, a barra pròpriamente dita, isto é, os bancos de areia que coroam a entrada do lado do mar aberto, estavam aumentando gradual mas lentamente. Isso é evidente pelo fato de que há cêrea de uns vinte anos havia ainda dois canais de acesso navegáveis, o principal abria-se defronte da entrada e era dirigido para leste, em direção ao mar aberto, sendo que o outro, o canal Sul, que acompanhava a certa distância a península da Ponta do Perigo (situada na Ilha do Cardoso), também se abria defronte da entrada e seguia até a Ponta de Itacurussá. Atualmente, a entrada é larga, profunda e possue cêrea de um quilômetro de largura. Repito: atualmente, porquanto ela está 
contìnuamente se alterando. De fato, a margem Sul da Ilha Comprida, limitada pela Ponta da Trincheira a W e pela Ponta de Fora a E, desloca-se de um modo geral, para o $\mathrm{N}$.

Citemos, primeiramente, o trabalho do historiógrafo de Cananéia, o Dr. A. Paulino de Almeida (Rev. Arq. Munic. v. 137, p. 51-67). à p. 63, relata o autor: "Como já dissemos, devido à forte corrente das águas, na barra de Cananéia, principalmente por ocasião das grandes marés, muito sofreu o extremo sul da Ilha Comprida, onde se verificou o fenômeno da erosão, dando lugar a uma sensível transformação quanto à forma do pontal, durante os últimos anos. E como as águas, dando volta ao mesmo, solapassem a rocha, que a pouco e pouco desmoronava, dentro em breve tão grande foi o avanço do mar que chegou a atingir o forte, desmoronando-se por completo"'. Um pouco mais adiante, no mesmo trabalho, lê-se que por volta de 1846 êsse forte foi desmantelado pela aproximação das águas. Não se sabendo a data exata da sua destruição, podese, todavia, supôr que ainda existisse nessa época.

Por outro lado, pelo testemunho dos moradores dessa parte da ilha, no decorrer das últimas duas gerações, várias casas foram destruídas pelo desmoronamento da margem. Segundo os mesmos testemunhos, a entrada alargou-se consideràvelmente, chegando alguns até a afirmar que duplicou sua largura. Não há dúvida que nada podemos afirmar sôbre essa base, mas, todavia, é incontestável o recúo para o $\mathrm{N}$ dessa margem da ilha. Nessa altura, poderíamos fazer algumas suposições. Assim, por exemplo, não há nenhuma indicação que leve a crêr que o forte da Ponta da Trincheira tenha sido deslocado anteriormente ao seu desaparecimento. Por outro lado, em vista da vegetação densa da ilha, é pouco provável que tenha sido, de início, construído a mais de uns cincoênta metros da beira. Segundo o autor acima citado $(1936$, p. 8) a primitiva fortificação data de 1544, sendo devida a Rui Moschera que retirando-se, mais tarde, para Santa Catarina, teria levado consigo "as peças de que dispunha, bem como todo o material bélico". Até 1803, não havia nenhuma fortificação em Cananéia, dando-se "a fundação do forte da barra e posse do comandante militar da vila" em setembro de 1824 (p. 21) mas, dez anos mais tarde "achava-se o forte mais ou menos abandonado" (p. 22).

No que concerne o fenômeno diante do qual nos encontramos, poderia tratar-se ou do alargamento da entrada ou do deslocamento dessa para o N. Atualmente, nada podemos dizer em favor de uma ou outra dessas alternativas. Pareceria provável, porém, dada a configuração da "Ponta do Perigo"', na Ilha do Cardoso, que constitue a margem $\mathrm{S}$ da entrada, que essa última, até tempos recentes, sofreu modificações muito menos intensas que a margem oposta.

Nós conhecemos, há já mais de 5 anos, a entrada. Durante êsse período, não tendo notado nenhuma alteração relevante, afora uma lenta erosão da margem, nos limitamos a observações superficiais. Todavia, durante o ano em curso (1952), apareceu tôda uma série de novos fenômenos. Os dois mais importantes são: uma intensificação acentuada da erosão da margem S da Ilha Comprida, sobretudo da Ponta da Trincheira, 
que está assoreando o canal $\mathrm{S}$, até agora a principal via de acesso à entrada da região lagunar. Finalmente, ainda mais recentemente, constatamos um ataque intenso do mar contra a praia que forma a costa voltada para o mar da Ilha do Cardoso, em direção à Ponta do Perigo. Todos êsses, assim como outros fatores, parecem indicar que estamos assistindo ao início de uma série de modificações profundas da principal entrada para todo o sistema lagunar.

Êsses fenômenos, se bem que puramente locais, podem apresentar algum interêsse geral e uma grande importância para o futuro de tôda a região lagunar e da população aí existente, Por essa razão, formamos uma pequena equipe cujos membros observarão certos apectos das modificações da costa, do ponto de vista topográfico e geológico, as alterações da Ilha Nova, modificações dos canais e das correntes.

Os resultados dessas observações serão gradualmente publicados sob a forma de "notas" e enfeixados sob a rubríca geral de: "Observações sôbre as modificações em curso na entrada de Cananéia, de sua barra e da região adjacente". ${ }^{(1)}$

(1) Dados gerais sôbre a região podem ser eneontrados em:

BESNARD, W., 1950. Considerações Gerais em tôrno da Região Lagunar de CananéiaIguape, I - Bol. Inst. Paul. Ocean., t. I, fase. 1, p. 9-26. S. Paulo.

BESNARD, W., 1950. Considerações Gerais em tôrno da Região Lagunar de CananéiaIguape, II - Bol. Inst. Paul. Ocean., t. I, fase. 2, p. 3-28. S. Paulo. 